\title{
PENGARUH RUANG TERBUKA PUBLIK TERHADAP TINGKAT KENYAMANAN SOSIAL PENGHUNI DI PERUMNAS TLOGOSARI SEMARANG
}

\author{
Putera Marhadika Wibowo*), Gagoek Hardiman, Atik Suprapti \\ *) Corresponding author email : putera.mw@gmail.com
}

Departemen Arsitektur, Fakultas Teknik, Universitas Diponegoro

\author{
Article info \\ MODUL vol 18 no 2, issues period 2019 \\ Doi $\quad: 10.14710 / \mathrm{mdl} .1 .1 .2020 .18-27$ \\ Received : 18 September 2019 \\ Revised :- \\ Accepted : 28 Maret 2020
}

\begin{abstract}
Perumnas Tlogosari adalah salah satu perumahan di Kota Semarang yang terdiri dari dua kelurahan yakni Kelurahan Tlogosari Kulon dan Kelurahan Muktiharjo Kidul. Perumahan ini dibangun pada tahun 1981 dan terus mengalami perkembangan yang juga dikuti dengan pertumbuhan jumlah penghuni perumahan tersebut. Seiring dengan bertambahanya jumlah penghuni Perumnas Tlogosari, maka diperlukan fasilitas umum untuk menunjang aktivitas dan memberikan kenyamanan sosial bagi para penghuni Perumnas Tlogosari, dimana salah satunya adalah ruang terbuka publik.

Penelitian ini bertujuan untuk mengetahui pengaruh dari fungsi ruang terbuka publik bagi kenyamanan sosial masyarakat. Penelitian ini menggunakan data primer yang diperoleh dengan menyebarkan kuesioner kepada penghuni Perumnas Tlogosari RW 20 Kelurahan Muktiharjo Kidul. Pengambilan sampel dilakukan dengan metode purposive sampling. Responden dalam penelitian ini berjumlah 50 orang responden. Dalam penelitian ini digunakan metode analisis Analisis Regresi Linear Berganda dan untuk pengujian hipotesis dilakukan dengan uji parsial.

Berdasarkan hasil dari penelitian ini didapatkan bahwa ruang terbuka publik yang mampu menjalankan semua fungsinya dapat memberikan kenyamanan sosial bagi masyarakat. Hal ini ditujukkan dari tingkat kenyamanan penghuni yang tinggi akibat fungsi dari ruang terbuka publik yang tercapai
\end{abstract}

Kata kunci: Ruang Terbuka Publik; Kenyamanan Sosial; Fungsi

Putera Marhadika Wibowo, Gagoek Hardiman, Atik Suprapti

\section{PENDAHULUAN}

Kota Semarang merupakan ibukota Jawa Tengah dengan jumlah penduduk sebesar 1.668.578 jiwa membuat Semarang menjadi salah satu kota terpadat di Indonesia dengan tingkat kepadatan penduduk sebesar 4.464 jiwa per kilometer persegi. Berbagai sarana dan prasarana untuk menunjang kehidupan masyarakat seperti perumahandibangun di setiap sudut kota. Pembangunan perumahan untuk penduduk kota Semarang tidak hanya dibangun oleh pemerintah, namun juga dari pihak swasta. Dengan adanya pembangunan perumahan yang dilakukan oleh pemerintah dan swasta, masyarakat dapat memilih perumahan dan kawasan permukiman untuk tinggal sesuai dengan kebutuhan masing-masing.

Menurut Undang-Undang nomor 1 tahun 2011 tentang Perumahan dan Kawasan Permukiman, perumahan wajib diengkapi rencana kelengkapan prasarana, sarana, dan utilitas umum. Salah satu sarana yang dimaksud yaitu ruang terbuka.

Berdasarkan Permen PU nomor 05/PRT/M/2008, ruang terbuka adalah ruang-ruang dalam kota atau wilayah yang lebih luas baik dalam bentuk area/kawasan maupun dalam bentuk area memanjang/jalur dimana dalam penggunaannya lebih bersifat terbuka yang pada dasarnya tanpa bangunan.

Menurut Permen PU nomor 12/PRT/M/2009, fungsi utama ruang terbuka adalah fungsi sosial budaya, dimana antara lain dapat berperan sebagai wadah aktifitas sosial budaya masyarakat dalam wilayah kota/kawasan perkotaan terbagi dan terencana dengan baik. Fungsi lain dari ruang terbuka yaitu sebagai pengungkapan ekspresi budaya/kultur lokal, media komunikasi warga kota, serta tempat olahraga, rekreasi, wadah dan objek pendidikan, penelitian, dan pelatihan dalam mempelajari alam.

Ruang terbuka publik yang ada berkaitan dengan tingkat kenyamanan penghuni. Kenyamanan merupakan komponen yang dapat merefleksikan secara langsung bagaimana tingkatan kualitas hidup masyarakat pada suatu wilayah. Kenyamanan yang dirasakan oleh warga diakibatkan oleh kondisi lingkungan yang sehat dan 
bersih (good and healthy environment), akses yang mudah dalam memperoleh kebutuhan hidupnya (economic viability) dan terciptanya hubungan sosial kemasyarakatan yang baik (social livability). Hubungan antar warga inilah yang menjadi kunci terhadap tingkat kenyamanan sosial.

Untuk mencapai kenyamanan sosial, perlu adanya wadah untuk berkumpul dan berinteraksi antar warga. Ruang terbuka publik di RW 20 Kelurahan Muktiharjo Kidul Perumahan Tlogosari merupakan salah satu ruang terbuka yang ada di Kota Semarang.

Ruang terbuka publik mempunyai beberpa fungsi seperti fungsi ekologis, fungsi estetis/arsitektural, dan fungsi sosial. Namun, kondisi ruang terbuka publik RW 20, Kelurahan Muktiharjo Kidul, Perumnas Tlogosari yang ada di masih belum memenuhi fungsi ruang terbuka yang baik.

Seiring dengan tingkat kesejahteraan masyarakat RW 20 yang semakin baik, dibutuhkan pula ruang terbuka publik yang yang mampu mengakomodasi kebutuhan masyarakat sekitar. Oleh karena itu pada tahun 2016 dilakukan revitalisasi dengan sumber dana yang berasal dari Dana Aspirasi DPRD Kota Semarang dan Iuran Warga. Revitalisasi dilakukan secara bertahap dan pada tahun 2019, seluruh pekerjaan dinyatakan selesai.

Akibat dari adanya revitalisasi, ruang terbuka publik menjadi lebih tertata, baik itu hard material dan soft materialnya, serta dan aktivitas sosial yang terjadi antar warga menjadi semakin intens. Dengan selesainya revitalisasi, ruang terbuka publik RW 20, Kelurahan Muktiharjo Kidul, diharapkan mampu memberikan kenyamanan sosial bagi penghuni..

\section{METODE}

\section{Pengumpulan Data}

Penelitian ini bertujuan untuk mengetahui bagaimana fungsi dari ruang terbuka publik berpengaruh terhadap kenyamanan sosial dari penghuni suatu kawasan yang mana dalam konteks penelitian ini diambil studi kasus pada Perumnas Tlogosari RW 20 Kelurahan Muktiharjo Kidul. Oleh karenanya penelitian ini menggunakan pendekatan kuantitatif.

Pendekatan kuantitatif adalah suatu pendekatan secara primer dengan menggunakan paradigma positivisme. Paradigma positivisme menganggap realitas sosial yang terjadi sebagai sesuatu yang bersifat empirik dan dapat diobervasi secara nyata (Irwan, 2018). Dalam pendekatan kuantitatif pengujian teori objektif dilakukan dengan menguji hubungan antara variabel, dimana variabel akan diukur dengan instrument penelitian, sehingga data yang dihasilkan dapat dianalisa secara statistik. Metode penelitian kuantitatif

1. Penetapan Obyek Penelitian

Menentukan obyek penelitian berdasarkan analisa
2. Penyebaran Kuisioner

Kuisioner disebar kepada penghuni di lingkungan sekitar obyek penelitian

3. Studi Pustaka

Menggunakan teori sebagai dasar penelitian dalam menentukan variabel-variabel

\section{Teknik Analisa}

Teknik analisis yang dipergunakan dalam penelitian ini adalah secara Deskriptif Kuantitatif. Adapun analisis yang dilakukan dalam mengkaji kenyamanan sosial penghuni di Perumnas Tlogosari antara lain:

1. Analisa Ruang Terbuka Publik

Bertujuan untuk mengetahui prinsip-prinsip ruang terbuka publik yang memenuhi indkator kenyamanan.

2. Analisa Kenyamanan Sosial

Bertujuan untuk mengetahui indikator dari kenyamanan sosial.

\section{KAJIAN PUSTAKA}

\section{Pengertian Ruang Terbuka Publik}

Menurut Carr (1992), ruang terbuka publik merupakan suatu ruang terbuka milik bersama, tempat masyarakat melakukan aktivitas fungsional dan ritualnya dalam suatu ikatan komunitas baik kehidupan seharihari maupun dalam perayaan berkala.

Menurut Iswanto (2006), ruang publik pada dasarnya ruang kosong (open space) yang sangat berguna, dengan adanya kekosongan bisa memuat berbagai aktivitas didalamnya. Selain itu, pada tata ruang kota dengan adanya open space / ruang terbuka untuk ruang pengikat kota sehingga ada jalinan atau penghubung antar ruang didalam kota.

Menurut Budiharjo (1998), ruang publik merupakan ruang yang direncanakan karena kebutuhan akan tempat-tempat pertemuan dan aktivitas bersama di udara terbuka.

Ruang publik merupakan ruang luar yang dipergunakan untuk aktivitas masyarakat sehari-hari (Gibbert 1972).

Sedangkan menurut Hakim (1993), ruang umum yang terbuka merupakan ruang terbuka di luar bangunan yang menampung aktivitas/kegiatan tertentu dan dapat digunakan oleh seluruh masyarakat, sehingga ruang terbuka sendiri memiliki bentuk terbuka di luar bangunan. Sebagai contoh ruang terbuka seperti taman, plaza, jalan, pedestrian, lapangan terbang, dan lapangan olahraga.

Ruang terbuka publik didesain untuk mempersatukan semua elemen komunitas. Oleh karena itu, ruang terbuka publik harus menjadi simbol dan alat dari perkembangan kota yang merefleksikan kehidupan sosial dan interaksi masyarakat. Ada suatu hubungan 
antara ruang terbuka publik dengan perkembangan kota, bahwa kegiatan dan aktivitas membentuk tempat dan menghubungkan langsung antara pengunjung dan ruang terbuka publik (Ramlee, et al. 2015).

\section{Fungsi Ruang Terbuka Publik}

Menurut Peraturan Menteri Pekerjaan Umum nomor 5/PRT/M/2008 tentang pedoman penyediaan dan pemanfaatan ruang terbuka non hijau di wilayah kota/kawasan perkotaan tahun 2008, fungsi ruang terbuka yaitu:

a. Fungsi sosial budaya, dimana antara lain dapat berperan sebagai:

- Wadah aktifitas sosial budaya masyarakat dalam wilayah kota/kawasan perkotaan terbagi dan terencana dengan baik;

- Pengungkapan ekspresi budaya/kultur lokal;

- Merupakan media komunikasi warga kota;

- Tempat olahraga dan rekreasi; dan

- Wadah dan objek pendidikan, penelitian, dan pelatihan dalam mempelajari alam.

b. Fungsi Ekologis

- Ruang terbuka mampu menciptakan suatu sistem sirkulasi udara dan air dalam skala lingkungan, kawasan dan kota secara alami berlangsung lancar (sebagai suatu ruang terbuka).

- Ruang terbuka berkontribusi dalam penyerapan air hujan (dengan bantuan utilisasi dan jenis bahan penutup tanah), sehingga mampu ikut membantu mengatasi permasalahan banjir dan kekeringan.

c. Fungsi Ekonomis

- ruang terbuka memiliki nilai jual dari lahan yang tersedia, misalnya sarana parkir, sarana olahraga, sarana bermain, dan lain sebagainya.

- ruang terbuka secara fungsional dapat dimanfaatkan untuk mengakomodasi kegiatan sektor informal sebagai bentuk pemberdayaan usaha kecil.

d. Fungsi Arsitektural

- Ruang terbuka meningkatkan kenyamanan, memperindah lingkungan kota baik dari skala mikro: halaman rumah, lingkungan permukiman, maupun makro: lansekap kota secara keseluruhan.

- Ruang terbuka dapat menstimulasi kreativitas dan produktivitas warga kota.

- Ruang terbuka menjadi salah satu pembentuk faktor keindahan arsitektural.

- Ruang terbuka mampu menciptakan suasana serasi dan seimbang antara area terbangun dan tidak terbangun.

e. Fungsi Darurat

- Ruang terbuka dalam mitigasi bencana alam dapat memiliki fungsi sebagai jalur evakuasi penyelamatan.
- Ruang terbuka secara fungsional dapat disediakan sebagai lokasi penyelamatan berupa ruang terbuka perkerasan yang merupakan tempat berkumpulnya massa (assembly point) pada saat bencana.

Dari beberapa pendapat mengenai fungsi dari ruang terbuka, dapat ditarik kesimpulan bahwa fungsi utama dari ruang terbuka yaitu merupakan wadah bagi masyarakat untuk bersosialisasi, berinteraksi, dan berkomunikasi dengan masyarakat lainnya. Fungsi lain yaitu dari segi ekologis sebagai ruang untuk pergantian udara dan menjadi paru-paru kawasan. Adapun dari segi arsitektural yakni memperindah estetika lingkungan dengan memanfaatkan hard material dan soft material sebagai bahan pembentuk ruang terbuka publik.

\section{Elemen ruang terbuka publik}

Ruang terbuka publik mempunyai berbagai macam elemen. Elemen inilah yang membentuk ruang terbuka publik menjadi citra di kawasan permukiman. Elemen ruang terbuka publik merupakan bagian dari lansekap. Menurut Rustam Hakim (2000) material lanskap dibagi menjadi dua yaitu:

a. Material lunak (soft material)

Material lunak berupa vegetasi dan air yang ada pada ruang terbuka publik

b. Material keras (hard material).

Material keras yang dibagi menjadi 5 antara lain:

- Material keras alami seperti bebatuan

- Material keras alami dari potensi geologi seperti batu pada tugu peringatan

- Material keras buatan bahan metal seperti signage, lampu taman, patung, dan lain-lain

- Material keras buatan sintetis/ tiruan seperti bak sampah dan papan nama

- Material keras buatan kombinasi seperti kursi taman yang terbuat dari batu yang dipadukan dengan bahan lainnya

Dari penjelasan diatas dapat disimpulkan bahwa ruang terbuka publik mempunyai berbagai macam material baik itu soft material dan hard material yang berfungsi sebagai pembentuk citra di suatu kawasan.

\section{Tipologi ruang terbuka publik}

Menurut Carr (1992), ruang terbuka publik di perkotaan mempunyai tipologi yang dikelompokan berdasarkan jenisnya. Dari pengelompokkan tersebut, yang merupakan ruang terbuka publik antara lain:

a. taman-taman publik (public parks)

b. lapangan dan plaza (square and plaza)

c. taman peringatan (memorial parks)

d. pasar (markets)

e. jalan (streets)

f. lapangan bermain (playground)

g. ruang terbuka untuk masyarakat (community open spaces) 
h. jalan hijau dan jalan taman (greenways and parkways)

i. atrium/pasar tertutup (atrium/indoor market place)

j. ruang terbuka yang dapat diakses oleh publik seperti sudut-sudut jalan, jalan menuju gedung, dan lain-lain (found spaces/everyday open spaces)

k. tepi laut (waterfronts)

\section{Pengertian Kenyamanan Sosial}

Menurut Kamus Besar Bahasa Indonesia, nyaman adalah segar; sehat. Sedangkan kenyamanan adalah keadaan nyaman, kesegaran, kesejukan.

Sanders dan McCormick (1993) menggambarkan konsep kenyamanan bahwa kenyamanan merupakan suatu kondisi perasaan dan sangat tergantung pada orang yang mengalami situasi tersebut. Kita tidak dapat mengetahui tingkat kenyamanan yang dirasakan orang lain secara langsung atau dengan observasi melainkan harus menanyakan langsung pada orang tersebut mengenai seberapa nyaman diri mereka, dengan menggunakan istilah-istilah seperti agak tidak nyaman, mengganggu, sangat tidak nyaman, atau mengkhawatirkan.

Menurut Kolcaba (2003), bahwa kenyamaan adalah kondisi dimana manusia telah memenuhi kebutuhan dasarnya yang bersifat individual dan holistik, sehingga tercipta perasaan sejahtera pada diri individu tersebut. Aspek kenyaman terbagi menjadi sebagai berikut :

a. Kenyamanan fisik, merupakan jenis kenyamanan yang dapat dirasakan langsung oleh sensasi tubuh setiap orang.

b. Kenyamanan psikospiritual, merupakan jenis kenyaman yang berkenaan dengan kesadaran internal diri, yang meliputi konsep diri, harga diri, makna kehidupan, seksualitas hingga hubungan yang sangat dekat dan lebih tinggi.

c. Kenyamanan lingkungan berkenaan dengan lingkungan, kondisi dan pengaruh dari luar kepada manusia seperti temperatur, warna, suhu, pencahayaan, suara, dll.

d. Kenyamanan sosial kultural berkenaan dengan hubungan interpesonal, keluarga, dan sosial atau masyarakat.

Manusia merupakan makhluk yang tidak dapat hidup sendiri tanpa adanya manusia lain. Oleh karena itu manusia disebut sebagai makhluk sosial. Hubungan sosial antar manusia akan melahirkan interaksi sosial. Menurut Setiadi (2011), interaksi sosial adalah hubungan-hubungan sosial yang dinamis yang berkaitan dengan orang perorangan, kelompok perkelompok, maupun perorangan terhadap perkelompok ataupun sebaliknya. Menurut Soekanto (2011), interaksi sosial adalah hubungan timbal balik antara individu dengan individu, individu dengan kelompok, dan kelompok dengan kelompok.

Dari definisi tentang kenyamanan dan manusia sebagai makhluk sosial, dapat diambil kesimpulan bahwa kenyamanan sosial adalah suatu kondisi nyaman yang dialami individu akibat adanya interaksi sosial antar individu lainnya. Kenyamanan sosial akan melahirkan kebudayaan dimana jaringan sosial di dalam masyarakat akan memiliki identitas yang kuat, tidak hanya di bidang tempat tinggal secara fisik, namun juga lingkungan hidup manusia.

\section{Livability sebagai komponen dalam Kenyamanan Sosial}

Kenyamanan sosial merupakan salah satu tujuan dari Kualitas Hidup. Kenyamanan yang dimaksud adalah kesempatan individu dalam melaksanakan aktifitasnya sehari-hari pada suatu kawasan untuk mendapatkan lingkungan yang bersih, daerah yang aman dari tindak kejahatan, serta daerah yang mempunyai akses terhadap fasilitas yang memadai sehingga aktifitas masyarakat dapat berlangsung tanpa harus timbul rasa khawatir dari masyarakat (Vitullo-Martin 1993).

Kualitas hidup merupakan hubungan yang integral antara tiga aspek yang saling mempengaruhi. Komponen tersebut adalah Livability, Viability, dan Sustainability. Ketiga aspek tersebut memiliki kedudukan yang sama dalam mempengaruhi kualitas hidup disuatu wilayah. Ketiga aspek kualitas hidup memiliki peran dan fokus pembahasan yang berbeda, yaitu; livability memiliki peran sebagai komponen yang menjelaskan tentang masalah-masalah sosial kemasyarakatan, viability menjelaskan tentang karakteristik perekonomian di suatu wilayah, sedangkan sustainability berperan untuk mengetahui kontribusi dan kualitas lingkungan hidup terhadap kualitas hidup.

Livability didefinisikan sebagai kualitas hidup penghuni pada suatu kota atau daerah (Timmer, 2005). Livability dapat berarti kenyamanan yang tercipta karena adanya pengaruh dari kondisi ruang dan aktifitas yang terjadi didalamnya terhadap manusia yang tinggal pada ruang tersebut (Gusman, 2003 dalam Silondae, 2010).

Menurut AARP Public Policy Institute, terdapat tujuh kategori dari livability antara lain:

a. Perumahan

Agar kualitas penghuni baik, maka perumahan harus memenuhi asas keterjangkauan, ketersediaan perumahan, dan akses perumahan. Perumahan yang baik memberikan peluang bagi siapapun dari perumahan bagi orang-orang dari segala usia, pendapatan, dan kemampuan, memungkinkan setiap orang untuk tinggal di lingkungan yang berkualitas terlepas dari keadaan mereka

b. Lingkungan 
Lingkungan yang ada dekat ke tujuan, terjaminnya keamanan individu, dan akses ke tempat tinggal, tempat bekerja, dan sarana rekreasi yang mudah.

c. Transportasi

Terdapat sarana transportasi yang aman, nyaman, serta biayanya terjangkau. Selain itu sarana transportasi yang ada bersifat universalitas yang artinya dapat diakses oleh semua orang tanpa terkecuali.

d. Lingkungan

Kebersihan udara menjadi faktor penting dalam index livability. Selain itu, ketersediaan air bersih, ketahanan lingkungan, dan efisiensi energi juga menjadi faktor yang mempengaruhi lingkungan.

e. Kesehatan

Akses ke fasilitas kesehatan dan kondisi kesehatan masyarakat memengaruhi perilaku kesehatan. Masyarakat yang sadar akan perilaku kesehatan mendorong lingkungan sekitar supaya berperilaku sehat seperti penyediaan fasilitas olahraga, penyediaan makanan sehat, dan penyediaan fasilitas kesehatan.

f. Keterlibatan

Suatu lingkungan dikatakan layak huni apabila ada keterlibatan masyarakat di setiap kegiatan sehingga akan tercipta interaksi sosial. Dengan adanya interaksi sosial diharapkan idak ada lagi kesenjangan sosial yang terjadi di masyarakat.

g. Peluang

Pendekatan yang digunakan untuk membangun dan mengembangkan sebuah lingkungan mengajak masuk dan mengikutsertakan semua orang dengan berbagai perbedaan kondisi, budaya, karakteristik, latar belakang, kemampuan, status, kondisi, etnik, budaya dan lainnya. sehingga semua orang dapat mempunyai hak . tingkat perekonomian, dan tingkat pendidikan yang sama.

\section{GAMBARAN UMUM}

Perumnas Tlogosari merupakan perumahan yang terlatak di Kecamatan Pedurungan, Kota Semarang Merupakan salah satu perumahan terbesar di Kota Semarang dengan luas lahan sebesar 170, 74 ha. Pembangunan Perumnas Tlogosari dimulai pada tahun 1986. Yang dilaksanakan oleh Perum Perumnas Regional V Perumnas Tlogosari dipisahkan menjadi 2 area, yakni area timur dan area barat yang dipisahkan oleh sebuah sungai. Batas-batas Perumnas Tlogosari antara lain:

a. Sebelah utara : Rel kereta api dan Kecamatan Genuk

b. Sebelah selatan: Jalan Arteri Soekarno-Hatta

c. Sebelah timur: Jalan Syuhada Raya

d. Sebelah barat : Jalan Tol
Secara administratif, terdapat 2 kelurahan yang berada di perumnas Tlogosari yakni kelurahan Tlogosari Kulon yang berada di sebelah selatan dan kelurahan Muktiharjo Kidul yang berada di utara

\section{Gambar 1}

Peta Tlogosari

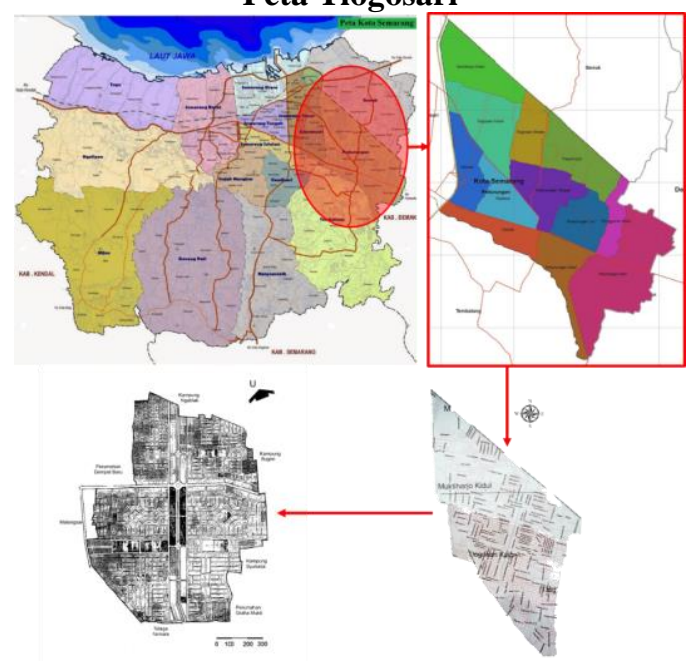

RW 20 merupakan salah satu Rukun Warga yang terdapat di Kelurahan Muktiharjo Kidul. Luas wilayah RW 20 yaitu $75.436 \mathrm{~m} 2$. Jumlah warga di RW 20 sebanyak 1359 orang yang terbagi menjadi dua, yakni dengan jenis kelamin laki-laki sebanyak 637 orang dan jenis kelamin perempuan sebanyak 722 orang.

\section{Gambar 2}

Peta RW 20, Kel. Muktiharjo Kidul

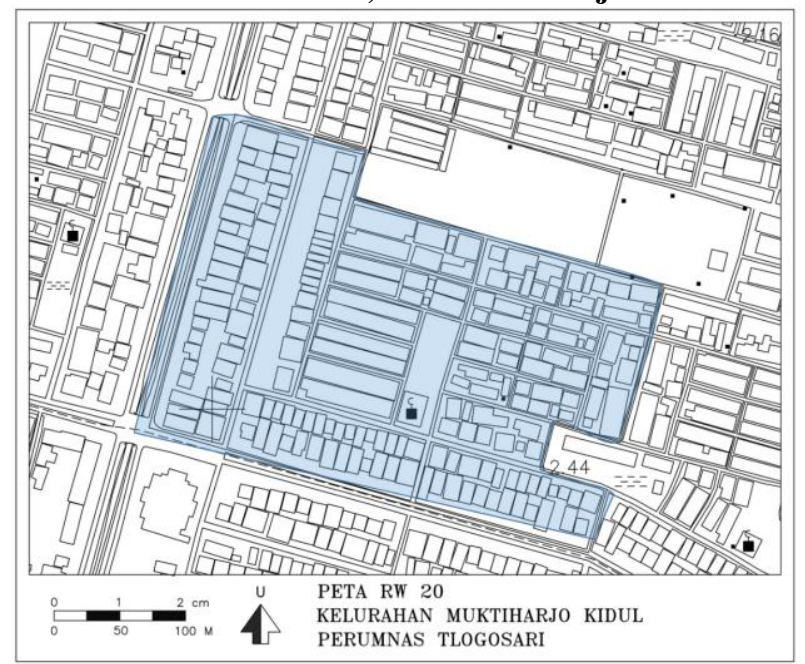

\section{Fasilitas Sosial}

Fasilitas sosial adalah fasilitas yang diadakan oleh pemerintah atau swasta yang dapat dimanfaatkan oleh masyarakat sekitar. RW 20 mempunyai fasilitas sosial yang digunakan oleh masyarakat yakni antara lain sebagai berikut: 
a. Fasilitas Pendidikan

Terdapat TK Raudhotul Jannah dan yang terdekat dengan RW 20 yakni SDN Muktiharjo Kidul 03.

b. Fasilitas Kesehatan

Fasilitas kesehatan yang ada yaitu Posyandu. Fasilitas kesehatan lain yang terdekat dengan RW 20 yakni Puskesmas Pembantu Muktiharjo Kidul.

c. Fasilitas Peribadatan

Terdapat 1 Masjid yakni masjid At-Taqwa.

d. Fasilitas Keamanan

Terdapat fasilitas keamanan yaitu Poskamling yang berada di RT 1, RT 2, RT 3, RT 7, dan RT 9

\section{Fasilitas umum}

Fasilitas umum adalah sarana dan prasarana yang disediakan oleh pemerintah yang digunakan untuk kepentingan umum dalam melaksanakan aktivitas sehari-hari. RW 20 mempunyai beberapa fasilitas umum yang digunakan oleh masyarakat yakni antara lain sebagai berikut:

a. Jalan

Terdapat akses berupa jalan dengan menggunakan dua bahan pelapis yaitu beton dan paving block

b. Lapangan olahraga dan tempat bermain anak Digunakan untuk senam, bola voli, dan sepak bola.

c. Drainase

Drainase terbuka dengan menggunakan saluran dari beton berukuran lebar $10 \mathrm{~cm}$. Aliran drainase dari setiap rumah dikumpulkan menuju saluran drainase lingkungan, selanjutnya dialirkan menuju drainase utama yang berada di sebelah barat.

d. Penerangan

Lingkungan RW 20 menggunakan lampu sebagai penerangan umum untuk aktivitas masyarakat di waktu malam. Penerangan ini tersebar di berbagai titik yang berada di jalan lingkungan maupun di ruang terbuka lainnya.

\section{Ruang Terbuka Publik di RW 20 Kelurahan Muktiharjo Kidul}

a. Ruang Terbuka Publik sebagai fungsi Sosial Budaya Digunakan untuk kegiatan dan interaksi antar warga yaitu lapangan

b. Ruang Terbuka Publik sebagai fungsi Ekologi Upaya untuk pelestarian lingkungan di Lingkungan RW 20 masih cukup baik. Hal ini dapat terlihat dari masih banyaknya ruang terbuka publik yang menggunakan paving block sebagai perkerasan, sehingga air masih bisa masuk menyerap ke dalam tanah

c. Ruang Terbuka Publik sebagai fungsi Arsitektural Terdapat Hard Material yang terdiri dari papan nama jalan, lampu penerangan, bak sampah, sitting group dan Soft Material berupa pepohonan dan tanaman hias

d. Ruang Terbuka Publik sebagai fungsi Ekonomi Mempunyai usaha berupa warung kelontong, bengkel, salon, usaha pulsa, toko alat tulis yang menjadi satu dengan hunian

e. Ruang Terbuka Publik sebagai fungsi Darurat Memiliki jalur penyelamatan atau evakuasi yang menjadi satu dengan jalan hunian dengan lebar 3 meter. Assembly point pada saat terjadi hal-hal darurat seperti kebakaran atau gempa bumi, di pusatkan di lapangan olahraga RW 20.

\section{ANALISA \& PEMBAHASAN}

\section{Variabel Penelitian dan Definisi Operasional}

Variabel penelitian yang digunakan ada dua yakni variabel dependen berupa tingkat kenyamanan sosial dan variabel independen berupa fungsi ruang terbuka publik dalam fungsi sosial budaya, fungsi ekologis, fungsi ekonomis, fungsi arsitektural, dan fungsi darurat

Tabel 1. Definisi Operasional Variabel

\begin{tabular}{|c|c|c|c|c|}
\hline NO & $\begin{array}{c}\text { Nama } \\
\text { variabel }\end{array}$ & $\begin{array}{l}\text { Definisi } \\
\text { variabel }\end{array}$ & indikator & sumber \\
\hline 1. & $\begin{array}{l}\text { Fungsi } \\
\text { Sosial } \\
\text { Ruang } \\
\text { Terbuka } \\
\text { Publik }\end{array}$ & $\begin{array}{l}\text { Ruang terbuka } \\
\text { publik yang } \\
\text { didasarkan pada } \\
\text { faktor sosial } \\
\text { budaya } \\
\text { masyarakat } \\
\text { setempat }\end{array}$ & $\begin{array}{l}\text {-Tersedianya ruang } \\
\text { untuk berkumpul } \\
\text { warga }\end{array}$ & $\begin{array}{l}\text { Permen } \\
\text { PU no } \\
\text { 12/PRT/ } \\
\text { M/2009 }\end{array}$ \\
\hline 2. & $\begin{array}{l}\text { Fungsi } \\
\text { Ekologi } \\
\text { Ruang } \\
\text { Terbuka } \\
\text { Publik }\end{array}$ & $\begin{array}{l}\text { Ruang terbuka } \\
\text { publik yang } \\
\text { didasarkan pada } \\
\text { kondisi } \\
\text { lingkungan }\end{array}$ & $\begin{array}{l}\text {-Terdapat vegetasi } \\
\text { pada ruang terbuka } \\
\text {-Sistem perembesan } \\
\text { air } \\
\text {-Sistem drainase } \\
\text {-Kebersihan udara }\end{array}$ & $\begin{array}{l}\text { Permen } \\
\text { PU no } \\
\text { 12/PRT/ } \\
\text { M/2009 }\end{array}$ \\
\hline 3. & $\begin{array}{l}\text { Fungsi } \\
\text { Arsitektural } \\
\text { Ruang } \\
\text { Terbuka } \\
\text { Publik }\end{array}$ & $\begin{array}{l}\text { Ruang terbuka } \\
\text { publik yang } \\
\text { didasarkan pada } \\
\text { elemen } \\
\text { arsitektural }\end{array}$ & $\begin{array}{l}\text {-Soft material } \\
\text {-Hard material } \\
\text {-Aksesibilitas } \\
\text {-Warna } \\
\text {-Tekstur } \\
\text {-Bentuk }\end{array}$ & $\begin{array}{l}\text { Permen } \\
\text { PU no } \\
\text { 12/PRT/ } \\
\text { M/2009 }\end{array}$ \\
\hline 4 & $\begin{array}{l}\text { Fungsi } \\
\text { Ekonomi } \\
\text { Ruang } \\
\text { Terbuka } \\
\text { Publik }\end{array}$ & $\begin{array}{l}\text { Ruang terbuka } \\
\text { publik yang } \\
\text { didasarkan pada } \\
\text { asas ekonomi }\end{array}$ & $\begin{array}{l}\text {-Tersedianya ruang } \\
\text { untuk menjalankan } \\
\text { aktivitas ekonomi }\end{array}$ & $\begin{array}{l}\text { Permen } \\
\text { PU no } \\
\text { 12/PRT/ } \\
\text { M/2009 }\end{array}$ \\
\hline 5 & $\begin{array}{l}\text { Fungsi } \\
\text { Darurat } \\
\text { Ruang } \\
\text { Terbuka } \\
\text { Publik }\end{array}$ & $\begin{array}{l}\text { Ruang terbuka } \\
\text { publik yang } \\
\text { didasarkan pada } \\
\text { pencegahan } \\
\text { bencana }\end{array}$ & $\begin{array}{l}\text {-Terdapat ruang } \\
\text { terbuka untuk jalur } \\
\text { evakuasi dari } \\
\text { bencana } \\
\text {-Terdapat ruang } \\
\text { terbuka untuk tempat } \\
\text { berkumpul massa } \\
\text { (assembly point) saat } \\
\text { terjadi bencana }\end{array}$ & $\begin{array}{l}\text { Permen } \\
\text { PU no } \\
\text { 12/PRT/ } \\
\text { M/2009 }\end{array}$ \\
\hline 6. & $\begin{array}{l}\text { Kenyamanan } \\
\text { Sosial }\end{array}$ & $\begin{array}{l}\text { Kondisi nyaman } \\
\text { yang dialami } \\
\text { individu akibat } \\
\text { adanya interaksi } \\
\text { sosial antar } \\
\text { individu lainnya }\end{array}$ & $\begin{array}{l}\text {-Keterjaminan } \\
\text { keamanan } \\
\text {-Ketersediaan sarana } \\
\text { transportasi } \\
\text {-Kemudahan akses } \\
\text {-Kebersihan } \\
\text { lingkungan } \\
\text {-Ketersediaan } \\
\text { fasilitas kesehatan } \\
\text {-Partisipasi } \\
\text { masyarakat tinggi } \\
\end{array}$ & $\begin{array}{l}\text { AARP } \\
\text { Public } \\
\text { Policy } \\
\text { Index }\end{array}$ \\
\hline
\end{tabular}




\begin{tabular}{l}
\hline -Persamaan hak antar \\
individu \\
\hline Deskripsi Variabel Penelitian \\
Dilakukan untuk mendapatkan gambaran deskriptif \\
mengenai responden penelitian ini, khususnya mengenai \\
variabel-variabel penelitian yang digunakan dengan \\
menggunakan Teknik Scoring dengan penggunaan \\
Three-box Method yang terbagi menjadi 1,00 - 2,33 = \\
Rendah; $2,34-3,67=$ Sedang; 3,68 - 5,00 = Tinggi
\end{tabular}

Tabel 2. Hasil Tanggapan Responden Terhadap Variabel Penelitian

\begin{tabular}{|c|c|c|c|c|c|c|}
\hline & $\mathrm{N}$ & Min & $\operatorname{Max}$ & Mean & $\begin{array}{c}\text { Std. } \\
\text { Deviation }\end{array}$ & Kategori \\
\hline \multicolumn{7}{|c|}{ Fungsi Sosial Budaya } \\
\hline $\mathrm{X} 1.1$ & 50 & 2 & 5 & 3.88 & 0.59 & Tinggi \\
\hline $\mathrm{X} 1.2$ & 50 & 2 & 5 & 3.84 & 0.62 & Tinggi \\
\hline $\mathrm{X} 1.3$ & 50 & 2 & 5 & 3.72 & 0.61 & Tinggi \\
\hline \multirow[t]{2}{*}{$\mathrm{X} 1.4$} & 50 & 3 & 5 & 3.76 & 0.48 & Tinggi \\
\hline & & Rata-rata & & 3.80 & & Tinggi \\
\hline \multicolumn{7}{|c|}{ Fungsi Ekologi } \\
\hline $\mathrm{x} 2.1$ & 50 & 3 & 5 & 3.94 & 0.47 & Tinggi \\
\hline $\mathrm{x} 2.2$ & 50 & 3 & 5 & 4.04 & 0.45 & Tinggi \\
\hline $\mathrm{x} 2.3$ & 50 & 2 & 5 & 4.04 & 0.60 & Tinggi \\
\hline \multirow[t]{2}{*}{$\mathrm{x} 2.4$} & 50 & 2 & 5 & 3.80 & 0.64 & Tinggi \\
\hline & & Rata-rata & & 3.96 & & Tinggi \\
\hline \multicolumn{7}{|c|}{ Fungsi Arsitektural } \\
\hline $\mathrm{x} 3.1$ & 50 & 3 & 5 & 4.16 & 0.55 & Tinggi \\
\hline $\mathrm{x} 3.2$ & 50 & 2 & 5 & 3.96 & 0.67 & Tinggi \\
\hline $\mathrm{x} 3.3$ & 50 & 2 & 5 & 3.98 & 0.62 & Tinggi \\
\hline x3.4 & 50 & 3 & 5 & 3.90 & 0.46 & Tinggi \\
\hline $\mathrm{x} 3.5$ & 50 & 2 & 5 & 3.88 & 0.59 & Tinggi \\
\hline x3.6 & 50 & 2 & 5 & 3.78 & 0.68 & Tinggi \\
\hline x3.7 & 50 & 3 & 5 & 3.90 & 0.54 & Tinggi \\
\hline x3.8 & 50 & 3 & 5 & 4.12 & 0.56 & Tinggi \\
\hline x3.9 & 50 & 2 & 5 & 4.04 & 0.70 & Tinggi \\
\hline \multirow[t]{2}{*}{$\mathrm{x} 3.10$} & 50 & 2 & 5 & 3.86 & 0.78 & Tinggi \\
\hline & & Rata-rata & & 3.96 & & Tinggi \\
\hline \multicolumn{7}{|c|}{ Fungsi Ekonomi } \\
\hline $\mathrm{x} 4.1$ & 50 & 2 & 5 & 4.00 & 0.64 & Tinggi \\
\hline \multirow[t]{2}{*}{$x 4.2$} & 50 & 3 & 5 & 3.82 & 0.56 & Tinggi \\
\hline & & Rata-rata & & 3.91 & & Tinggi \\
\hline \multicolumn{7}{|c|}{ Fungsi Darurat } \\
\hline $\mathrm{x} 5.1$ & 50 & 3 & 5 & 4.20 & 0.53 & Tinggi \\
\hline \multirow[t]{2}{*}{ x5.2 } & 50 & 3 & 5 & 4.04 & 0.57 & Tinggi \\
\hline & & Rata-rata & & 4.12 & & Tinggi \\
\hline \multicolumn{7}{|c|}{ Kenyamanan Sosial } \\
\hline y. 1 & 50 & 2 & 5 & 3.84 & 0.65 & Tinggi \\
\hline y. 2 & 50 & 2 & 5 & 3.86 & 0.61 & Tinggi \\
\hline y. 3 & 50 & 2 & 5 & 3.90 & 0.79 & Tinggi \\
\hline y. 4 & 50 & 2 & 5 & 3.84 & 0.65 & Tinggi \\
\hline y. 5 & 50 & 2 & 5 & 3.82 & 0.75 & Tinggi \\
\hline y. 6 & 50 & 2 & 5 & 3.86 & 0.64 & Tinggi \\
\hline \multirow[t]{2}{*}{ y.7 } & 50 & 3 & 5 & 3.92 & 0.60 & Tinggi \\
\hline & & Rata-rata & & 3.86 & & Tinggi \\
\hline
\end{tabular}

Berdasarkan perhitungan diatas menunjukkan bahwa penilaian terhadap semua fungsi Ruang Terbuka Publik menunjukkan dalam kondisi penilaian yang baik. Kondisi demikian mencerminkan bahwa responden warga menilai akan tingginya semua fungsi dari Ruang Terbuka Publik di Perumnas Tlogosari.

\section{Uji Validitas Data}

Uji validitas data dalam penelitian ini dilakukan dengan koefisien korelasi. Nilai korelasi yang lebih besar dari 0,279 , maka kuesioner tersebut dikatakan valid

Tabel 3. Hasil Pengujian Validitas

\begin{tabular}{|c|c|c|c|}
\hline $\mathrm{No}$ & Variabel & r hitung & $\mathrm{r}$ tabel \\
\hline
\end{tabular}

\begin{tabular}{|c|c|c|c|c|}
\hline \multirow[t]{5}{*}{1} & Sosial Budaya & & & \\
\hline & 1 & 0.830 & 0,279 & Valid \\
\hline & 2 & 0.877 & 0,279 & Valid \\
\hline & 3 & 0,749 & 0,279 & Valid \\
\hline & 4 & 0.712 & 0,279 & Valid \\
\hline \multirow[t]{5}{*}{2} & Ekologi & & & \\
\hline & 1 & 0.728 & 0,279 & Valid \\
\hline & 2 & 0.704 & 0,279 & Valid \\
\hline & 3 & 0.82255 & 0,279 & Valid \\
\hline & 4 & 0.850 & 0,279 & Valid \\
\hline \multirow[t]{11}{*}{3} & Arsitektural & & & \\
\hline & 1 & 0.693 & 0,279 & Valid \\
\hline & 2 & 0.787 & 0,279 & Valid \\
\hline & 3 & 0.709 & 0,279 & Valid \\
\hline & 4 & 0,656 & 0,279 & Valid \\
\hline & 5 & 0,741 & 0,279 & Valid \\
\hline & 6 & 0,689 & 0,279 & Valid \\
\hline & 7 & 0,796 & 0,279 & Valid \\
\hline & 8 & 0,557 & 0,279 & Valid \\
\hline & 9 & 0,725 & 0,279 & Valid \\
\hline & 10 & 0,790 & 0,279 & Valid \\
\hline \multirow[t]{3}{*}{4} & Ekonomi & & & \\
\hline & 1 & 0.942 & 0,279 & Valid \\
\hline & 2 & 0.924 & 0,279 & Valid \\
\hline \multirow[t]{3}{*}{5} & Darurat & & & \\
\hline & 1 & 0.880 & 0,279 & Valid \\
\hline & 2 & 0.895 & 0,279 & Valid \\
\hline \multirow[t]{8}{*}{5} & Kenyamanan & & & \\
\hline & 1 & 0.861 & 0,279 & Valid \\
\hline & 2 & 0.839 & 0,279 & Valid \\
\hline & 3 & 0.825 & 0,279 & Valid \\
\hline & 4 & 0.885 & 0,279 & Valid \\
\hline & 5 & 0.824 & 0,279 & Valid \\
\hline & 6 & 0.900 & 0,279 & Valid \\
\hline & 7 & 0.889 & 0,279 & Valid \\
\hline
\end{tabular}

Tabel 3 menunjukkan bahwa semua indikator yang digunakan untuk mengukur variabel-variabel yang digunakan dalam penelitian ini mempunyai koefisien korelasi dengan signifikansi lebih besar dari 0,279. Dengan demikian semua indikator tersebut adalah valid

\section{Uji Reliabilitas Data}

Uji reliabilitas dimaksudkan untuk mendapatkan data yang reliabel. Selanjutnya uji realibilitas pada pengujian ini menggunakan Cronbach Alpha $(\alpha)$, dimana jika $\alpha>$ 0,60 maka kuesioner dikatakan kosisten atau reliabel.

\section{Tabel 4. Hasil Pengujian Reliabilitas}

\begin{tabular}{lccc}
\hline \multicolumn{1}{c}{ Variabel } & Alpha & Kondisi & Keterangan \\
\hline Sosial Budaya & 0,803 & $>0,60$ & Reliabel \\
Ekologi & 0,780 & $>0,60$ & Reliabel \\
Arsitektural & 0,892 & $>0,60$ & Reliabel \\
Ekonomi & 0,847 & $>0,60$ & Reliabel \\
Darurat & 0,730 & $>0,60$ & Reliabel \\
Kenyamanan Sosial & 0,938 & $>0,60$ & Reliabel \\
\hline
\end{tabular}

Hasil uji reliabilitas tersebut menunjukkan bahwa semua variabel mempunyai koefisien Alpha yang cukup besar yaitu diatas 0,60 sehingga dapat dikatakan semua konsep pengukur masing-masing variabel dari kuesioner adalah reliabel sehingga untuk selanjutnya item-item pada masing-masing konsep variabel tersebut layak digunakan sebagai alat ukur. 


\section{Uji Normalitas}

Pengujian normalitas dilakukan terhdap residual regresi.Pengujian dilakukan dengan menggunakan PP Plot dan menggunakan Uji Kolmogorov Smirnov.

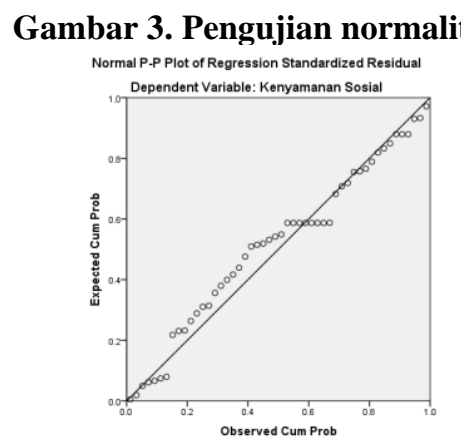

Gambar 3 tersebut menunjukkan bahwa PP Plot sudah mendekati garis diagonal yang menunjukkan daya yang berdistribusi normal.

Tabel 5. Pengujian Normalitass

\begin{tabular}{llr}
\hline & & Unstandardized Residual \\
$\mathrm{N}$ & Mean & 50 \\
\hline Normal Parameters $^{\mathrm{a}, \mathrm{b}}$ & Std. & .0000000 \\
& Deviation & 2.00114060 \\
Most Extreme Differences & Absolute & .110 \\
& Positive & .088 \\
& Negative & -.110 \\
Test Statistic & & .110 \\
Asymp. Sig. (2-tailed) & $.182^{\mathrm{c}}$ \\
\hline a. Test distribution is Normal. & \\
b. Calculated from data. & \\
c. Lilliefors Significance Correction. &
\end{tabular}

\section{Pengujian Multikolinieritas}

Pengujian multikolinieritas dilakukan dengan menggunakan nilai VIF. Suatu variabel menunjukkan gejala multikolinieritas bisa dilihat dari nilai VIF (Variance Inflation Factor) yang tinggi pada variabelvariabel bebas suatu model suatu model regresi. Nilai VIF dari variabel bebas pada model regresi adalah sebagai berikut:

Tabel 6

\begin{tabular}{lrr}
\multicolumn{3}{c}{ Pengujian Normalitass } \\
\hline & Tolerance & V IF \\
\hline Sosial Budaya & 0.639 & 1.565 \\
Ekologi & 0.486 & 2.057 \\
Arsitektural & 0.506 & 1.975 \\
Ekonomi & 0.508 & 1.969 \\
Darurat & 0.486 & 2.058 \\
\hline
\end{tabular}

Hasil pengujian menunjukkan bahwa nilai VIF dari semua variabel bebas memiliki nilai yang lebih kecil dari 10. Hal ini berarti bahwa variabel-variabel penelitian tidak menunjukkan adanya gejala multikolinieritas dalam model regresi

\section{Pengujian Heteroskedastisitas}

Uji ini bertujuan untuk menguji apakah dalam model regresi terjadi ketidaksamaan varian residual antara yang satu dengan yang lain. Jika varian residual dari satu pengamatan ke pengamatan yang lain tetap maka disebut homokedastisitas. Dan jika varians berbeda, disebut heterokedastisitas. Model regresi yang baik adalah tidak terjadi heterokedastisitas.

Untuk mengetahui ada tidaknya gejala heterokedastisitas dapat dilakukan dengan menggunakan grafik heterokedastisitas antara nilai prediksi variabel dependen dengan variabel indepeden

\section{Gambar 3. Uji Heterokedastisitas Scatter Plot}

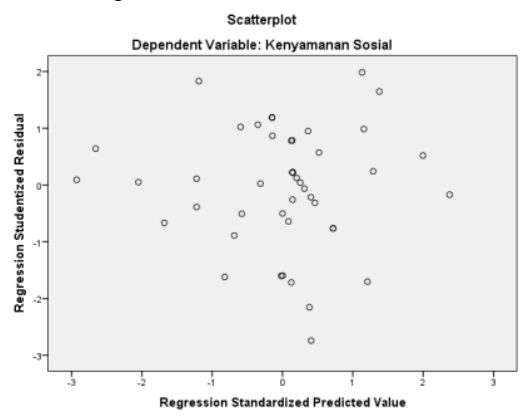

Uji heteroskedastisitas dengan Scatter Plot menunjukkan adanya pola yang menyebar yang mengindikasikan tidak adanya masalah heteroskedastisitas dalam model regresi.

Tabel 7. Uji Heterokedastisitas Glejser

\begin{tabular}{|c|c|c|c|c|c|c|}
\hline \multirow{2}{*}{\multicolumn{2}{|c|}{ Model }} & \multicolumn{2}{|c|}{$\begin{array}{c}\text { Unstandardized } \\
\text { Coefficients }\end{array}$} & \multirow{2}{*}{$\begin{array}{c}\begin{array}{c}\text { Standardized } \\
\text { Coefficients }\end{array} \\
\text { Beta } \\
\end{array}$} & \multirow[b]{2}{*}{ t } & \multirow[b]{2}{*}{ Sig. } \\
\hline & & B & Std. Error & & & \\
\hline \multirow[t]{6}{*}{1} & (Constant) & -.686 & 2.021 & & -.339 & .736 \\
\hline & Sosial Budaya & -.149 & .125 & -.212 & -1.192 & .240 \\
\hline & Ekologi & .202 & .154 & .267 & 1.310 & .197 \\
\hline & Arsitektural & -.009 & .058 & -.030 & -.148 & .883 \\
\hline & Ekonomi & -.043 & .229 & -.038 & -.189 & .851 \\
\hline & Darurat & .236 & .267 & .180 & .884 & .382 \\
\hline & ependent Variab & AbsRes & & & & \\
\hline
\end{tabular}

Uji heteroskedastisitas dengan uji Glejser menunjukkan tidak adanya variabel yang signifikan terhadap nilai mutlak residualnya yang mengindikasikan tidak adanya masalah heteroskedastisitas dalam model regresi.

\section{Analisis Regresi Linear Berganda}

Pengujian hipotesis dilakukan dengan analisis regresi berganda. Analisis regresi berganda digunakan untuk hipotesis tentang pengaruh variabel secara simultan mampu untuk menguji hipotesis tentang pengaruh antar variabel independen atau secara parsial.

Tabel 8. Tabel Koefisien Persamaan Regresi Linear

\begin{tabular}{|c|c|c|c|c|c|c|}
\hline \multirow{2}{*}{\multicolumn{2}{|c|}{ Model }} & \multicolumn{2}{|c|}{$\begin{array}{c}\text { Unstandardized } \\
\text { Coefficients }\end{array}$} & \multirow{2}{*}{$\begin{array}{c}\text { Standardized } \\
\text { Coefficients } \\
\text { Beta }\end{array}$} & \multirow[b]{2}{*}{$\mathrm{t}$} & \multirow[b]{2}{*}{ Sig. } \\
\hline & & $\mathrm{B}$ & Std. Error & & & \\
\hline & (Constant) & -10.333 & 3.335 & & 3099 & .003 \\
\hline & Sosial Budaya & .493 & .206 & .224 & 2.389 & .021 \\
\hline & Ekologi & .518 & .255 & .219 & 2.032 & .048 \\
\hline & Arsitektural & .203 & .096 & .223 & 2.115 & .040 \\
\hline & Ekonomi & .794 & .378 & .221 & 2.098 & .042 \\
\hline & Darurat & .907 & .441 & .221 & 2.055 & .046 \\
\hline
\end{tabular}


Model penelitian dapat ditulis sebagai berikut:

$Y=-10,333+0,493 X 1+0.518 X 2+0,204 X 3+0,794$

$\mathrm{X} 4+0,907 \mathrm{X} 5+\mathrm{e}$

Hasil tersebut dapat dijelaskan sebagai berikut:

a. Koefisien regresi variable fungsi Sosial Budaya terhadap Kenyamanan sosial diperoleh sebesar 0,493. Arah positif tersebut menunjukkan bahwa gungsi sosial budaya yang lebih baik akan meningkatkan kenyamanan sosial

b. Koefisien regresi variable fungsi Ekologi terhadap Kenyamanan sosial diperoleh sebesar 0,518. Arah positif tersebut menunjukkan bahwa fungsi ekologi lebih baik akan meningkatkan kenyamanan sosial.

c. Koefisien regresi variable fungsi Arsitektural terhadap Kenyamanan sosial diperoleh sebesar 0,203 . Arah positif tersebut menunjukkan bahwa fungsi arsitektural yang lebih baik akan meningkatkan kenyamanan sosial.

d. Koefisien regresi variable fungsi Ekonomi terhadap Kenyamanan sosial diperoleh sebesar 0,794. Arah positif tersebut menunjukkan bahwa fungsi ekonomi yang lebih baik akan meningkatkan Kenyamanan sosial.

e. Koefisien regresi variable fungsi Daeurat terhadap Kenyamanan sosial diperoleh sebesar 0,907. Arah positif tersebut menunjukkan bahwa fungsi darurat yang lebih baik akan meningkatkan kenyamanan sosial.

Model tersebut diatas menunjukkan bahwa semua koefisien regresi memiliki arah sebagaimana yang diharapkan. Selanjunya hasil tersebut dapat diinterpretasikan untuk besarnya nilai dari masingmasing koefisien regresinya.

\section{Uji Model (Uji F)}

Pengujian model penelitian berupa pengaruh variabel bebas secara bersama-sama terhadap variabel terikatnya dilakukan dengan menggunakan uji F. Dari hasil perhitungan statistik dengan menggunakan SPSS diperoleh sebagai berikut

Tabel 9 Uji F

\begin{tabular}{|c|c|c|c|c|c|}
\hline Model & $\begin{array}{l}\text { Sum of } \\
\text { Squares }\end{array}$ & df & $\begin{array}{c}\text { Mean } \\
\text { Square }\end{array}$ & F & Sig. \\
\hline \multirow{3}{*}{$\begin{array}{ll}1 & \text { Regression } \\
& \text { Residual } \\
& \text { Total } \\
\end{array}$} & 595.696 & 5 & 119.139 & 26.715 & $.000^{\mathrm{b}}$ \\
\hline & 196.224 & 44 & 4.460 & & \\
\hline & 791.920 & 49 & & & \\
\hline $\begin{array}{l}\text { a. Dependent } \\
\text { b. Predictors: } \\
\text { Ekologi }\end{array}$ & $\begin{array}{l}\text { Kenyaman } \\
\text { t), Darurat, }\end{array}$ & $\begin{array}{l}\text { Sosial } \\
\text { sial Bu }\end{array}$ & & 1, & \\
\hline
\end{tabular}

Tabel 9 diperoleh nilai $F$ Model adalah sebesar 26,715 dengan tingkat signifikansi 0,000 . Jika dilihat dari nilai signifikansi $\mathrm{F}$ tersebut diperoleh bahwa nilai sig $\mathrm{F}$ lebih kecil dari 0,05. Hal ini berarti bahwa variabel fungsi sosial budaya, Ekologi, Arsitektural, Ekonomi dan fungsi Darurat dapat menjelaskan kenyamanan sosial yang diperoleh.

\section{Koefisien Deteterminasi $\left(\mathbf{R}^{\mathbf{2}}\right)$}

Maksud dan tujuan koefisien determinasi adalah mengukur besarnya kemampuan model persamaan regresi (independen variables) dalam menerangkan variabel terikat.

Tabel 10. Koefisien Determinasi

\begin{tabular}{l|c|r|c|c}
\hline Model & $\mathrm{R}$ & R Square & $\begin{array}{c}\text { Adjusted R } \\
\text { Square }\end{array}$ & $\begin{array}{c}\text { Std. Error of the } \\
\text { Estimate }\end{array}$ \\
\hline 1 & $\begin{array}{r}.867 \\
\mathrm{a}\end{array}$ & .752 & .724 & 2.11178 \\
\hline
\end{tabular}

Pada tabel 10 ditunjukkan nilai Adj. R2 pada model regresi diperoleh sebesar 0,724 yang artinya 72,4\% variasi Kenyamanan sosial dapat dijelaskan oleh variabel independen fungsi sosial budaya, Ekologi, Arsitektural, Ekonomi dan fungsi Darurat, sedangkan sisanya sebesar $27,6 \%$ kenyamanan sosial dapat dijelaskan oleh faktor-faktor lainnya.

\section{KESIMPULAN DAN REKOMENDASI}

\section{Kesimpulan}

a. Fungsi sosial budaya berpengaruh positif dan signifikan terhadap kenyamanan sosial. Semakin baik fungsi sosial budaya akan meningkatkan kenyamanan sosial.

b. Fungsi ekologi berpengaruh positif dan signifikan terhadap kenyamanan sosial. Semakin baik fungsi ekologi akan meningkatkan kenyamanan sosial.

c. Fungsi arsitektural berpengaruh positif dan signifikan terhadap kenyamanan sosial. Semakin baik fungsi arsitektural akan meningkatkan kenyamanan sosial.

d. Fungsi ekonomi berpengaruh positif dan signifikan terhadap kenyamanan sosial. Semakin baik fungsi ekonomi akan meningkatkan kenyamanan sosial.

e. Fungsi darurat berpengaruh positif dan signifikan terhadap kenyamanan sosial. Semakin baik fungsi darurat akan meningkatkan kenyamanan sosial.

\section{Rekomendasi}

Berdasarkan kesimpulan yang diperoleh dalam penelitian ini, maka didapat saran-saran sebagai berikut yaitu pembangunan ruang terbuka publik berpengaruh ke tingkat kenyamanan sosial penghuni. Dibutuhkan regulasi yang lebih ketat bagi pengembang sebuah perumahan baik itu pengembang lama maupun pengembang baru, bahwa ruang terbuka publik keberadaannya wajib ada Apabila sudah ada, harus ditingkatkan lagi kualitasnya supaya lingkungan yang dibangun dapat membuat penghuni merasa nyaman. 


\section{REFERENSI}

AARP Public Policy Institute (2018) "The Livability Index 2018: Transforming Communities for All Ages." Washington DC.

Budiharjo, Eko (1998) Kota Yang Berkelanjutan. Jakarta: Direktorat Jenderal Pendidikan Tinggi Departemen Pendidikan dan Kebudayaan.

Carr, Stephen (1992) Public Space. Cambridge: Cambridge University Press.

Hakim, Rustam, and Hardi Utomo (2003) Komponen Perancangan Arsitektur Lansekap, PrinsipUnsur dan Aplikasi Desain. Jakarta: Bumi Aksara.

Iswanto, Danoe (2006) "Kajian Ruang Publik Ditinjau Dari Segi Proporsi / Skala Dan Enclosure." ENCLOSURE - Jurnal Ilmiah Perancangan Kota dan Permukiman .

Kolcaba, Katharine (2003)Comfort Theory and Practice: A Vision for Holistic Health Care and Research. New york: Springer Publishing Company.

Kuncoro, Mudrajad (2003) Metode Riset untuk Bisnis dan Ekonomi. Jakarta: Erlangga.

Manik, K.E.S (2003) Pengelolaan Lingkungan Hidup . Jakarta: Djambatan.

Muhadjir, N (2000) Metodologi Penelitian Kualitatif Edisi IV. Yogyakarta: Rake Sarasin.

PermenPU nomor 05/PRT/M/2008 (2011) "Pedoman Penyediaan Dan Pemanfaatan Ruang Terbuka Hijau Di Kawasan Perkotaan." Jakarta.

PermenPU nomor 12/PRT/M/2009 (2009) "Pedoman Penyediaan Dan Pemanfaatan Ruang Terbuka Non Hijau Di Wilayah Kota/Kawasan Perkotaan.” Jakarta.

Ramlee, Maimunah, Dasimah Omar, Rozyah Mohd Yunus, and Zalina Samadi (2015)

Revitalization of Urban Public Spaces: An Overview. Procedia - Social and Behavioral Sciences Volume 201 360-367.

Sanders, Mark S., and Ernest McCormick (1993) Human Factors In Engineering and Design. New York: Mcgraw-Hill Book Company.

Setiadi, Elly M, Kolip, and Usman (2011) Pengantar Sosiologi. Pemahaman Fakta dan Gejala Permasalahan Sosial: Teori, Aplikasi, dan Pemecahannya. Jakarta: Kencana.

Silondae, Irhansyah Umar (2010) Kondisi Lingkungan Perumahan Dalam Konteks Kenyamanan Hidup (Studi Kasus : Perumahan Kendari Permai Kota Kendari). Semarang: UNDIP.

Soekanto, Soerjono (2011) Sosiologi Suatu Pengantar. Jakarta: Rajawali Press.

Supomo, Bambang, and Nur Indriantoro (1999) Metodologi Penelitian Bisnis Untuk Akuntansi dan Manajemen. Yogyakarta: BPFEYogyakarta.

Timmer, Vanessa (2005) The Livable City: Vancouver Working Group Discussion Paper. Canada: Vancouver Working Group.

Vitullo-Martin, Julia (1993) "The Livable City : Confronting the Quality of Life ." City Journal Vol 3, No 4, Autumn 27-33. 